\title{
The Evaluation and Enlightenment of Student Loan Policy for Higher Education in Australia
}

\author{
Yi Chen \\ Department of Academic Affairs \\ Beihang University \\ Beijing, China
}

\author{
Kexin Han \\ School of Economics and Management \\ Beihang University \\ Beijing, China
}

\begin{abstract}
In order to further improve the policy of student loan and accelerate the healthy development of higher education in China, this work proposes some feasible suggestions to perfect the policy of student loan for higher education in China. A thorough comprehension of Australian student loan policy for higher education and a comparison of student loan policy in various aspects between Australian and China are presented in this study to achieve the aim. In doing this, the conclusions that Australia is famous for its relatively impeccable student loan policy such as a wide range of student loans, clear application scope of loans, flexible and reasonable repayment methods, and progressive repayment amount according to the proportion of income are discovered, which is thought to be referential experience for China. In the final, some advice for higher education student loan in China is proposed from the following aspects: refining the types of loans, accurately determining the upper limit, improving the repayment mechanism, strengthening the loan funding, and enhancing the policy orientation.
\end{abstract}

Keywords—student loan; development history; policy measures; comparative analysis

\section{INTRODUCTION}

As the fees of higher education continue to increase, funding for students with financial difficulties has become a worldwide consensus. Countries around the world pay increasingly attention to student loan. As an effective means to optimize the funding structure, promote education equity and social justice, student loan plays a prominent role in the funding policy system.

Many scholars have studied Australian higher education student loan policy. They found that Australia has great advantages in student loan policy. There are also many scholars doing researches on the system of student loan for higher education in China. It is found that many deficiencies in the current higher education student loan system exist in China. For example, the variety is not abundant enough, and the implementation is not strong enough.

To further improve China's student loan system, this paper combs out the types and policy measures of Australian higher education student loan and summarizes the experience of Australia on the basis of reviewing the development history of Australian higher education student loan system. A comparative analysis of student loan policy between Australia and China is also presented in this study.
To this end, data and information are collected from extensive sources. In Section 2, the development history of the Australian student loan policy for higher education is given.

In Section 3, the context introduces the policy design for higher education student loan in Australia. In Section 4, the comparison of student loan between China and Australia is presented. In the final task, this study shows a brief conclusion and some feasible suggestions on the higher education student loan in China.

\section{The Development History of Australian Student LOAN POLICY FOR HIGHER EDUCATION}

In 1989, the Hawker Labor Government announced to implement the Higher Education Contributions Scheme (HECS), which determined that higher education costs should be shared by the federal government and students. In 1996, the Howard Coalition Government kept on the HECS system and established a three-tier cost structure of HECS. That is, tuition fees are set by the future expected value of the course. For example, students majoring in law and medicine may obtain high-income after graduation so they pay courses with higher tuition while students majoring in art courses with lower future expected income will pay relatively less tuition. In 2005, the Howard Coalition Government announced to replace the previous HECS loan with Higher Education Loan Program (HELP) loan [1].

Since the establishment of higher education loan scheme, the number of students receiving financial aid has increased year by year. For example, the number of applicants for VET FEE HELP alone has increased from 5262 in 2009 to 272000 in 2015 [2]. The Australian government has invested a lot in this program. In 2015-2016, the financial expenditure reached 2.444 billion Australian dollars, and the Australian government continues to increase subsidies for this program. The total budget for 2016-2017 reached 2.61 billion Australian dollars [3].

\section{The Policy Design of Australian Higher Education STUDENT LOAN}

\section{A. Policy types of Higher Education Loan Program}

The HELP can be divided into the following five categories according to the purpose of student loans. 


\section{1) HECS-HELP}

HECS-HELP helps eligible federally funded students to pay their student contribution through loans or prepaid discounts. In the HECS-HELP loan, students only need to pay a part of the tuition fee, which is called "student contribution", and the balance is paid by the federal government [4].

\section{2) FEE-HELP}

Non-federally funded students are known as "Full Fee Paying Students," for whom the federal government does not provide direct funding. The FEE-HELP program aids eligible students in paying part or all of their tuition excluding additional study costs such as accommodation and books [5].

\section{3) SA-HELP}

The SA-HELP helps students to pay for some or all of their student services and amenities, such as sports and leisure activities, employment and career advice, child care, financial advice and food services [6].

4) OS-HELP

The OS-HELP helps eligible students to pay for their overseas learning expenses, including air tickets, accommodation and other travel or learning expenses. Students can get an OS-HELP loan every six months during their study period, and the total number of such loans cannot exceed twice during the whole study period [7].

5) VET FEE-HELP

The VET FEE-HELP helps eligible students enrolled in high-level vocational education and training courses to pay for their tuition fees.

Brief conclusions of the five types of student loans for higher education in Australia are presented in Table I.

TABLE I. FIVE TYPES OF STUDENT LOANS FOR HIGHER EDUCATION IN AUSTRALIA

\begin{tabular}{|c|c|c|c|}
\hline Table Head & \multicolumn{3}{|c|}{ Australia HELP Loan } \\
\hline Loan types & Application restriction & Loan purpose & Upper limit of amount \\
\hline HECS-HELP & Federally funded students & $\begin{array}{l}\text { Student contribution paid by way of loans or } \\
\text { prepaid discounts }\end{array}$ & Student contribution \\
\hline FEE-HELP & Fully paid students & $\begin{array}{l}\text { Some or all tuition fees excluding additional } \\
\text { learning costs }\end{array}$ & $\begin{array}{l}\text { The cumulative loan with VET } \\
\text { FEE-HELP does not exceed } \$ 99389 \text {, } \\
\text { and the special subject is } \$ 124238\end{array}$ \\
\hline SA-HELP & $\begin{array}{l}\text { Australian citizen, New Zealand special visa } \\
\text { holder eligible for long term residence, } \\
\text { permanent humanitarian visa holder }\end{array}$ & $\begin{array}{l}\text { Pay for part or all of the student services and } \\
\text { amenities (e.g. sports and leisure activities, } \\
\text { employment and career advice, etc.) }\end{array}$ & $\$ 290$ \\
\hline OS-HELP & $\begin{array}{l}\text { Australian citizen, New Zealand special visa } \\
\text { holder eligible for long term residence, } \\
\text { permanent humanitarian visa holder }\end{array}$ & $\begin{array}{l}\text { Help eligible students to pay for their overseas } \\
\text { study expenses, including air tickets, } \\
\text { accommodation and other travel or study expenses }\end{array}$ & $\begin{array}{l}\text { Generally \$6470, \$7764 for Asia, } \\
\text { \$1035 for additional language learning }\end{array}$ \\
\hline $\begin{array}{l}\text { VET } \\
\text { FEE-HELP }\end{array}$ & $\begin{array}{l}\text { The course is registered with vet FEE-HELP } \\
\text { and the corresponding diploma is provided }\end{array}$ & $\begin{array}{l}\text { Help qualified students who are enrolled in } \\
\text { high-level vocational education and training } \\
\text { courses to pay tuition fees }\end{array}$ & $\begin{array}{l}\text { The accumulated loan with FEE-HELP } \\
\text { does not exceed } \$ 99389 \text {, and the } \\
\text { special subject is } \$ 124238 \text {. }\end{array}$ \\
\hline
\end{tabular}

\section{B. Application conditions}

The application conditions for HELP loan are relatively loose except for specific requirements of HECS-HELP and FEE-HELP. Clear qualifications are imposed by HELP loan on providers of higher education courses. For instance, HECS-HELP loan requires students to attend schools in Australia, and foreign schools are not eligible for application.

\section{Tuition and loan ceiling}

The student contribution in HECS-HELP loan is not decided by the upper limit of tuition fees according to the course cost but decided by the expected income of students after graduation. Institutions of higher education can determine student contributions every school year under the condition that student contribution should not exceed the maximum tuition set up by the government and actual demand of students.

\section{Tax support}

The repayment of the HELP loan is guaranteed by the tax system. In the case of applying for a loan, applicants are required to provide their tax file number (TFN) which is a special number issued by the tax authorities. Applicants need to provide the TFN application certificate issued by the Australian Taxation Office (ATO) when he/she doesn't have the TFN. By doing this, the tax department will automatically deduct corresponding repayment amount from the income of the student when the income of the student exceeds the minimum repayment threshold.

\section{E. Repayment by income proportion}

A repayment policy for HELP loans based on the income ratio is established by Australian government. According to the personal income of the borrower after-tax, the Australian government divides the income into ten levels and nine thresholds. Each income level corresponds to a fixed loan compulsory repayment ratio. The higher the income, the higher the compulsory repayment ratio.

\section{F. Loan interest, prepayment and delayed repayment}

The HELP loan does not charge any interest, but the interest will be adjusted on June 1 of each year according to the annual CPI. Prepayment is allowed and voluntary repayment allowance is provided by Australia. Currently, if the prepayment is more than $\$ 500$, an allowance of $5 \%$ of the amount paid will be obtained by pay person and directly deducted from the repayment amount. When the lender is in serious economic difficulties and cannot repay on time, the lender can turn to ATO for a delayed repayment so long as he or she provides a detailed description of family income and expenditure to prove the serious difficulties.

\section{G. HECS-HELP allowance}

The HECS-HELP allowance is a measure reducing HELP debt repayment of students to encourage graduates to pursue 
specific careers or work in designated locations. For example, Students engaging in mathematics and science, early childhood care, nursing, education can apply for HECS-HELP allowance. The allowance is decided by the total amount of debt at graduation and the time spent working in a designated occupation.

\section{THE COMPARISON OF STUDENT LOAN BETWEEN CHINA AND AUSTRALIA}

At present, China has formed a higher education loan system including the national student loans, student origin credit student loans, tuition reimbursement loans compensatory and other ways. The comprehensive comparison between China and Australia's student loan system is shown in Table II.

TABLE II. THE COMPARISON OF STUDENT LOAN BETWEEN CHINA AND AUSTRALIA

\begin{tabular}{|c|c|}
\hline Table head & The comparison \\
\hline Nation & Australia \\
\hline Nature & Policy loan \\
\hline Agency & $\begin{array}{l}\text { Universities, public and private higher education } \\
\text { institutions, the Australian ministry of education and } \\
\text { training, the Internal Revenue Service }\end{array}$ \\
\hline Application place & State in which the student borrows residency \\
\hline $\begin{array}{l}\text { Application } \\
\text { condition }\end{array}$ & $\begin{array}{l}\text { Australian citizen or permanent holder of Australian } \\
\text { visa, the person who meets tax filing requirements and } \\
\text { has no record of tax evasion }\end{array}$ \\
\hline Ceiling & $\begin{array}{l}\text { HECS-HELP: student contributions; FEE-HELP and } \\
\text { VET FEE-HELP: \$99389; OS-HELP: \$6470; } \\
\text { SA-HELP: \$290 }\end{array}$ \\
\hline Repayment way & Automatically deducted by the tax system \\
\hline Repayment rate & $\begin{array}{l}\text { The interest rate is not fixed and adjusted based on CPI } \\
\text { every year }\end{array}$ \\
\hline $\begin{array}{l}\text { Repayment } \\
\text { amount }\end{array}$ & Repayment in proportion to income \\
\hline $\begin{array}{l}\text { Mortgage } \\
\text { guarantee }\end{array}$ & Unsecured \\
\hline Repayment time & $\begin{array}{l}\text { Once the income exceeds the mandatory repayment } \\
\text { threshold (even if still learning) }\end{array}$ \\
\hline Repayment term & No provision, all debt relief over 65 years of age \\
\hline Early repayment & $\begin{array}{l}\text { Prepayment is allowed and a } 5 \% \text { voluntary repayment } \\
\text { allowance is provided }\end{array}$ \\
\hline $\begin{array}{l}\text { Breach of } \\
\text { contract }\end{array}$ & $\begin{array}{l}\text { Warning and punishment by ATO or transfers to the } \\
\text { judicial department }\end{array}$ \\
\hline Risk-prevention & Federal compensation \\
\hline
\end{tabular}

\section{CONCLUSION AND POLICY SUGgESTIONS}

Based on the analysis of Australian student loan policy for higher education, and comparison on student loan policy for higher education between Australian and China. This paper concludes that Australian have strong advantages in higher education loan policy which is worth learning from China. China can learn a lot from the following fives aspects:

A. Refining the types of student loans and clarify the scope of use

There are many kinds of student loans with clear purposes in Australia. Loan applications do not affect each other. The clear scope of loan application helps to avoid the waste caused by the cross scope of loan application. China can learn something from those.

\section{B. Providing loans based on demand, and accurately determining the loan ceiling}

Higher education tuition in Australia has made a clear division in terms of disciplines and specialties. According to the expected future income brought by the courses, the upper
Chent loan between China and Australia

China

Policy loan

Commercial banks, China development bank and higher education institutions Native place or campus

The person who possesses Chinese nationality or Chinese resident identity card is in financial difficulties

Undergraduate: $8000 ¥$ per year a person

Postgraduate: $12000 ¥$ per year a person

Postal savings, rural credit cooperatives, Alipay and so on

The rate is fully subsidized by government when the lender is in school period, and the lender shall pay the interest in accordance with the legal loan interest rate published by the people's Bank of China after graduation

Based on the agreement with the bank Credit guarantee

Students can choose to repay the loan from any month within 24 months after graduation

13 years after graduation, the loan term plus repayment term shall not exceed 20 years

A written application shall be submitted to the bank. The principal of prepayment shall be charged with interest according to the interest rate agreed in the contract and the actual days of use

Penalty interest shall be calculated and collected according to the actual overdue amount and overdue days. The penalty interest rate is $130 \%$ of the normal loan interest rate

A special fund for risk compensation of national student loan shall be established, which shall be borne by the finance department and general university respectively by $50 \%$

limit of tuition fees for different disciplines has been set. The establishment of tuition fees according to the expected future income can reduce the default rate of loans, and to a certain extent avoid the lack of funding or waste, which is a good example to China.

\section{Improving the repayment mechanism and scientifically designing the repayment system}

The effective recovery of loan funds is the basis and guarantees to avoid funding exhaustion and ensure the sustainable development of student loans. Australia has adopted a sound tax system to automatically recover loans based on income, which is also worth learning.

\section{Reducing the interest rate appropriately and strengthening} the subsidizing nature of loans

Although the government compensates for the loan interest during the period of students' study, $100 \%$ of the self-paid loan interest will still bring heavy repayment burden to students after graduation. With the fierce competition in the employment market and the prolongation of graduates' employment period, the phenomenon of default of principal 


\section{ACKNOWLEDGMENT}

and interest will be more serious. So the interest adjusted based on CPI in Australia is adaptable for China. In this context, China should appropriately reduce the loan interest rate and increase the government's subsidy to student loans.

\section{E. Perfecting loan system and improve policy guidance}

Australia provides HECS-HELP allowance for special occupations and workplaces to support and encourage graduates to engage in related work, which plays a huge role in promoting the development of related industries. Similarly, in order to guide and encourage college graduates to work in the western region and the hard and remote areas, China has established various loan compensation systems, such as Tuition and Loan Compensation for Community Workers, Tuition and Loan Compensation\& Tuition Reduction for Enlisted Soldiers, Tuition and Loan Compensation for Junior Military Officers and so on. However, the implementation process is cumbersome, and the proportion of graduates who get compensation funding is very low. China should vigorously promote the construction process of the compensation system, simplify the compensation process, enrich and expand the scope and types of compensation, encourage and guide students to participate in the construction of the motherland.
The authors would like to thank associate prof. Song for his ideas and supports. The authors are also very thankful to the reviewers of the manuscript for important suggestions to increase the quality of the paper.

\section{REFERENCES}

[1] Y.Ge, Z.Zhu. Australian university student funding policy and its reform. Comparative education research, 2006, 27 (6): 45-49. in Chinese.

[2] Redesign VET FEE-HELP: Discussion Paper. Department of Education $\begin{array}{lll}\text { and Training [EB/OL]. [2016-4-27]. https://docs. } & \end{array}$ education.gov.au/node/40661.

[3] Portfolio Budget Statements. Department of Education and Training [EB/OL]. [2016-5-3]. https://docs.education.gov.au/node/40551

[4] HELP Loans and CSPs. Study Assist [EB/OL]. [2016-12-10]. http://studyassist.gov.au/sites/studyassist/helppaying/myfees/hecs-help/ pages.

[5] FEE-HELP, Study Assist [EB/OL]. [2016-12-10] http://studyassist.gov.au/sites/rassist/ helppayingmyfees/fee-help/pages/fee-help

[6] SA-HELP, Study Assist [EB/OL]. [2016-12-10]. http://studyassist.gov.au/sites/_ studyassist/ helppayingmyfees/sa-help/pages/sa-help

[7] OS-HELP Loans and Overseas Study, Study Assist [EB/OL]. [2016-12-10]. http://studyassist.gov.au/sites/studyassi st/helppayingmyfees/os-help_overseas_study/pages/os-help-loans-and-s tudy-overseas 